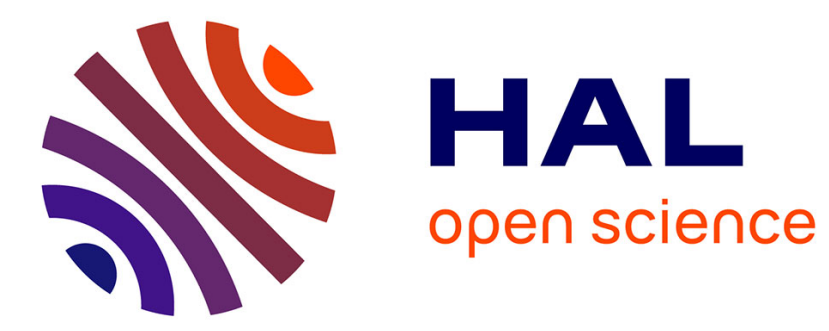

\title{
Serum therapy against FMD and the development of the French veterinary profession in the 1930s
}

Delphine Berdah

\section{To cite this version:}

Delphine Berdah. Serum therapy against FMD and the development of the French veterinary profession in the 1930s. Review of Agricultural, Food and Environmental Studies, 2021, 102 (2), pp.151-169. 10.1007/s41130-020-00108-w . halshs-03178172

\section{HAL Id: halshs-03178172 \\ https://shs.hal.science/halshs-03178172}

Submitted on 14 Jun 2021

HAL is a multi-disciplinary open access archive for the deposit and dissemination of scientific research documents, whether they are published or not. The documents may come from teaching and research institutions in France or abroad, or from public or private research centers.
L'archive ouverte pluridisciplinaire HAL, est destinée au dépôt et à la diffusion de documents scientifiques de niveau recherche, publiés ou non, émanant des établissements d'enseignement et de recherche français ou étrangers, des laboratoires publics ou privés. 


\title{
Serum therapy against FMD and the development of the French veterinary profession in the 1930s
}

\section{Delphine Berdah ${ }^{1}$ (D)}

Received: 17 June 2019 / Accepted: 21 May 2020 / Published online: 11 June 2020

(C) INRAE and Springer-Verlag France SAS, part of Springer Nature 2020

\begin{abstract}
This article focuses on the development of the French veterinary profession in the twentieth century and on the importance of sera and vaccines production and use in that process. As an example, it will follow the trajectory of sera against foot-and-mouth disease - a disease disastrous for agricultural production - from the very first researches on viruses and immunization to the production of "immunizing agents" by veterinarians from the veterinary services or by private laboratories that the sanitary norm of controlling animal diseases in France let free to develop and sell during the 1930s. Based on various sources - national archives, archives from private pharmaceutical industries, professional veterinary journals and interviews of retired veterinarians - this paper reveals a completely different image of France often depicted as a state-controlling country through a body of civil servants. On the contrary, it shows how local and private initiatives prevailed in the control of contagious diseases of animals, leaving veterinarians free to establish special relations with farmers and pharmaceutical industries, which were essential to the development of their profession. The paper argues finally that the use of syringes containing sera - and later vaccines - reinforced the medical role of veterinarians who saw both financial benefits in the direct sale of these products and also the core meaning of their work as practitioners of animal medicine.
\end{abstract}

This article is a socio-historical study which relies on various sources: national archives from the Ministry of Agriculture and its veterinary services; archives from the expert body of contagious animal diseases, the Comité Consultatif des Epizooties (Advisory Committee on Epizootics) whose task was to advise the Ministry of Agriculture on the policy to follow; archives from private pharmaceutical industries such as the Mérieux Institute; personal archives of Ludovic and Pierre Blaisot, a physician and a veterinarian involved in the production and use of sera in Normandy. This article also relies on the careful study of professional veterinary journals and especially the journal of the French veterinary union (le Bulletin du Syndicat National des Vétérinaires Français) and also on some interviews of retired veterinarians.

Delphine Berdah

delphine.berdah@universite-paris-saclay.fr

Extended author information available on the last page of the article 
Keywords Veterinary medicine $\cdot$ Professionalization $\cdot$ Serum therapy $\cdot$ Foot-and-mouth disease $($ FMD $) \cdot$ Pharmaceutical industries $\cdot$ Immunization

\section{Introduction}

All histories of veterinary medicine in the nineteenth century-either in Europe, Australia or North America - share the same general background, that of veterinary surgeons in competition with non-qualified practitioners (farriers, cow leachers, etc....) in regard to the care and protection of animal health. The involvement of veterinarians in the control of contagious diseases through the application of sanitary policies (isolation, disinfection of the premises and slaughtering of contagious animals), thanks to their clinical knowledge of animal diseases, empowered them in the last quarter of the nineteenth century with the mandate to maintain healthy herds, both for the trade and internal production, on behalf of European states (Fisher 1993; Hubscher 1999; Worboys 1991 and Worboys 1992; Wilkinson 1992; Woods 2004, Woods and Matthews 2010, Woods 2011 and Woods 2013; Waddington 2004 and Waddington 2006; Hardy 2003; Schäffer and Koolmees 2003; Berdah 2018). In France however, this nineteenth-century mandate was defective in the sense that veterinarians were only responsible for the control of contagious animal diseases, mainly at the borders and in some fairs and markets. That meant non-qualified practitioners were still able to perform medicine for animals as long as their diseases were not spreading to others. These practitioners maintained their influence in most parts of the country, all the more given that qualified veterinarians were few in number, and still lacking prestige and reputation, despite famous representatives (Hubscher 1999; Berdah 2012). In some countries such as Germany or the Netherlands, the control of contagion drove veterinarians towards their involvement in the protection of public health, through the careful control of milk and meat in slaughterhouses, engaging themselves forward in the career of civil servants (Koolmees 1988; Mitsuda 2017). French veterinarians followed the same path, with the creation of the status of departmental veterinarians (later veterinary officers) in charge of meat inspection in slaughterhouses, in 1909. However, this professional segment was unappealing to the large majority of practitioners, more prone to private practice, as the working conditions (salary, number of colleagues, number of slaughterhouses to inspect, fairs and markets under their jurisdiction...) varied a lot, depending on local administrative authorities (Conseil Général Vétérinaire 2006). Thus, despite the recognition of their ability to prevent contagion to either humans or animals, veterinarians were still "not quite a profession" ${ }^{1}$ " in the first quarter of the twentieth century. This paper focuses on the development of the French veterinary profession in the twentieth century and reveals a completely different image of France often depicted as a state-controlling country through a body of civil servants, centralizing decisions and power in Paris. On the contrary, the French government in the 1930s appears reluctant to engage itself financially in the control of animal diseases and more prone to favour local and private initiatives. This article argues that, in that special configuration, contrary to other professions such as physicians or lawyers (Friedson 1988 (1986); Karpik 1995) and to veterinarians in most of the occidental

\footnotetext{
${ }^{1}$ In reference to Fisher's paper (1993).
} 
countries, French veterinarians took assistance not only from the State in the development of their profession but also from other social worlds such as private laboratories producing therapeutic substances, as well as farmers. This article will follow the trajectory of the serum against foot-and-mouth disease - a disease disastrous for agricultural production - from the very first researches on viruses and immunization to the production of "immunizing agents" by veterinarians from the veterinary services or by private laboratories. Based on various sources - national archives from the Ministry of Agriculture and its veterinary services; archives from the expert body of contagious animal diseases: the Advisory Committee on Epizootics (Comité Consultatif des Epizooties); archives from private pharmaceutical industries; professional veterinary journals and some interviews of retired veterinarians - this paper will study how this special relationship with farmers and pharmaceutical industries served the development of the French veterinary profession. Building on their success against foot-and-mouth disease, veterinarians demonstrated how the control of contagious diseases was not only a matter of dealing with sick animals but also of preserving the healthy from infection, thanks to their expertise on the making and using of sera. In doing so, veterinarians developed an interaction network between humans (veterinarians, industrialists, farmers) and non-humans (sera and vaccines) essential for the extension of their monopoly from the medicine of contagious animals to the medicine of all animals, where the use of the "syringe" was to be a decisive mediator into the establishment of a confidence relationship between farmers and veterinarians. The paper argues finally that this use of syringes containing sera - and later vaccinesreinforced the medical role of veterinarians who saw both financial benefits in the direct sale of these products and also the core meaning of their work as practitioners of animal medicine.

\section{The French veterinary control of contagious animal diseases and the importance of sera and vaccines in their repertoire of action, c. 1881-1930}

In the last quarter of the nineteenth century, France suffered from a British embargo on her importations of French meat, because of a fear of contagious diseases endemic on the Continent. As a reaction, a sanitary policy — similar to the British law ${ }^{2}$ — was passed in 1881, giving the French veterinarians the monopoly on the control of contagious animal diseases, thus defining their first jurisdiction. This monopoly recognized the special competences of veterinarians over the diagnosis of contagion as the basis of the whole sanitary policy: having diagnosed the contagiousness of a disease, such as sheep scab, sheep pox and foot-and-mouth disease, the veterinarians imposed on the contaminated area the isolation of the sick animals and their contacts and froze fairs, markets and animal movements. If the veterinarians diagnosed cattle plague, pleuropneumonia, anthrax, rabies and glanders, the sanitary policy was reinforced by the seizure and the slaughter of the infected animals. However, despite this stringent legislation, the secondary norms of application - that means, according to the sociologist Pierre Lascoumes, "standards for the application of reference rights" resulting from "direct

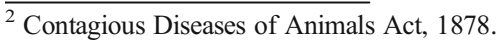


or indirect negotiations amongst the stakeholders involved in their application"-were much moderate (Lascoumes 1990). Indeed, France was still dominate by small exploitations where multiple activities were performed, in order to resist to the many uncertainties of agriculture (Mayaud 2000). Most of the farms had no more than ten cows for milk, sold on local markets or straight on the farm. ${ }^{3}$ Except for some regions in North West France, there was no cattle breeding and the production remained destined for local consumption (Stanziani 2005). Tractors were nearly non-existent, making agricultural labour dependent on animal force: first horses, but as they were often too expensive, oxen (Mayaud 2002). As a consequence, the slaughtering of sick bovines - absolutely indispensable for the harvests - was a measure impossible to apply and non-lethal diseases were most of the time handled by farmers themselves, according to the experience they had of the disease, in many different ways (Berdah 2018). For example, foot-and-mouth disease (FMD) was perceived a mild but very contagious disease of cattle, causing ulcerations around the mouth, hooves and udders, preventing them from standing (this is why farmers had nicknamed the disease "cocotte", referring to prostitutes on heels), and also from eating, thus cutting short lactation and farm labour. Foot-and-mouth disease has long been considered an "economic" problem, impeding the maximization of profits from agricultural goods (especially as various subtypes of the virus exist and can make the caws sick many times a year, in the same manner as the flu virus). In the beginning of the twentieth century, FMD was nearly enzootic in France, meaning that the disease was always somewhere in the country. Farmers were used to dealing with its consequences. They could either accelerate the process of contagion - a technique called "aphtisation", which consisted in infecting all the cattle from the same herd at the same time, by collecting secretions from ulcerations of a sick animal with a towel to rub the jaws of the other animals with - in order to get rid of the disease quicker (Blancou 2003).

They could also apply various folk remedies transmitted from generation to generation, mostly based on natural antiseptics such as salt and vinegar (Jouët 1912), or thyme and wild thyme (Morandi n.d.), applied to the wounds and bandaged up, to prevent the complications of the disease (today known to be due to superinfections). These remedies were prepared and delivered by farmers or by folk practitioners, showing evidence of the existence of a medical market for contagious animals despite the 1881 Act, largely tolerated — or at least not sanctioned - by the French government. Farmers, non-qualified practitioners and veterinarians could also buy the same drugs, such as "Aphto-vital" produced by Rhône-Poulenc or "Luzeol-cheroux" produced by the Cheroux Laboratories, ${ }^{4}$ as there was no regulation on veterinary pharmacy in France until 1975 (drugs for animals were freely sold either from pharmacies, veterinarians, cooperatives, groceries, rural markets or hawkers). Thus, non-qualified practitioners and veterinarians had more or less the same repertoire of therapeutic actions than farmers, and veterinarians, often considered more expensive than non-qualified practitioners, had hardly access to animals suffering from foot-and-mouth disease, despite the legislation.

\footnotetext{
${ }^{3}$ Centre Historique des Archives Nationales, F 10-5431: Production Laitière. Rapports pour l'Assemblée Nationale sur les produits des Chambres d'Agriculture, par Robineau, secrétaire de la Chambre d'Agriculture de l'Yonne et Achard, secrétaire de la Confédération Générale des Producteurs de Lait, 15 et 16 mars 1932.

${ }^{4}$ Centre des Archives Contemporaines, Fonds des Services Vétérinaires, Cote: 19880158, Article 105.
} 
One specific tool however was exclusively the jurisdiction of veterinarians: that of sera and vaccines, not because of the difficulty of the technical skill of injection but because of a special partnership developed with the Pasteur Institute, the leader in the making of these substances in France at the beginning of the twentieth century. Contagious diseases and collaborations with veterinarians had been at the centre of the investigations of Pasteur Institute even before its creation, since the very first researches of Louis Pasteur on fowl cholera, swine erysipelas, anthrax and of course rabies. First, some professors of veterinary medicine from the veterinary schools of Lyon and Toulouse had started to experiment on contagious diseases and immunization before Louis Pasteur was well known for his vaccine discoveries (such as Henri Toussaint, Jean-Baptiste Chauveau or Pierre Victor Galtier). Their researches, communicated at the Academy of Science, guided as an aviso (Fleck 2005 (1934)) the master's researches and the competition with some of them even served Louis Pasteur more than he would have confessed (Geison 1997 (1995)). Second, veterinarians were also present besides Louis Pasteur very early in the process of fabrication of his vaccines, as animals were needed for the researches and the culture of viruses, and veterinarians were indispensable to get them fit for this task (Rosset 2003). Some of them-the most famous of which was Edmond Nocard, Professor at the Veterinary School of Alfort (then Director) - were even involved in leading programs of research at the Pasteur Institute (rabies, cholera) or in the practical validation of the vaccines through the clinical observation of the symptoms of the animals, once vaccinated and tested with an infectious injection (such as Henri Bouley and Hippolyte Rossignol for the anthrax vaccines at Pouilly-le-Fort). As Maurice Cassier has well shown, the media coverage of the trial of Pouilly-le-Fort settled a truly association between the Pasteur Laboratory (and later the Pasteur Institute) and the French agricultural policy, which granted their researches and enabled Pasteur and his colleagues to experiment their vaccines at a large scale on animals from the farms depending on the Ministry of Agriculture or through grants allocated to the trials (Cassier 2008). This system was financially essential for the beginning of the Pasteur Institute and the vaccines produced there represented a real market of veterinary products (Cassier 2005). Thus, from the beginning, the interests of the Pasteur Institute and those of the veterinary profession were intertwined, making Louis Pasteur admit his debt to Henri Bouley who contributed to make contagious animal diseases at the centre of the French public agenda. ${ }^{5}$

Engaged besides Louis Pasteur, Edmond Nocard was amongst the first to teach bacteriological skills adapted to veterinary medicine in the "microbie" lecture at the Pasteur Institute. At the same time, the three national veterinary schools of Lyon, Alfort and Toulouse provided lectures in bacteriology, bacteria cultures and diagnostics of contagion. Moreover, the book of students who attended the microbial lecture of Emile Roux at the Pasteur Institute shows that many veterinarians came to the Pasteur Institute to complete their training. Thus, at the end of the nineteenth century, a certain veterinary elite got involved in physiological and bacteriological research, trying to pull the entire profession out of the traditional skills of the forge and the hooves of horses that were

\footnotetext{
${ }^{5}$ Quoting Pasteur in Rosset (2003) p. 9: "S'il m'était permis de parler de moi et des doctrines microbiennes, je dirais que ces dernières années, lui [Henri Bouley] qui est. conquérant par la parole, il a rendu par son impétuosité réfléchie la victoire facile. Nous tous, messieurs, depuis ses plus vieux camarades jusqu'aux plus jeunes vétérinaires à peine sortis de l'École, nous avons une dette de reconnaissance à proclamer ici."
} 
closer to the non-qualified practitioners' know-how (Berdah 2012). The appropriation of this bacterial knowledge reached a peak with the Research Laboratory on Contagious Diseases of Animals (the "Laboratoire de recherche sur les maladies infectieuses des animaux") created at Alfort Veterinary School in $1901 .^{6}$ At that time, the government entrusted the veterinarians from the Parisian school to investigate foot-and-mouth disease on a "scientific" basis, in order to find alternatives to the sanitary policy which was impossible to put in practice on a large scale (Eme 1912). Apparently, the Pasteur Institute had previously declined the proposition to investigate such a disease, and the veterinarians appeared the second "experts" in microbiology and animal diseases in France, just after the famous Institute. ${ }^{7}$ This recognition of a veterinary knowledge in bacteriology through the creation of a laboratory destined to pursue the same kind of research as the Pasteur Institute's on the Ministry of Agriculture's behalf is significant of the role of bacteriology and the association of the veterinarians with the Pasteur Institute as an "engine" of social promotion for the veterinary profession. Their involvement in the production of prophylactic products eventually was granted by a second jurisdiction on serum production. Indeed, the decree of February, 4, 1937, which standardized the conditions of production and control of "sera from living animals", gave a special status to veterinarians as scientific directors of the production centres of sera. ${ }^{8}$ This decree recognized explicitly the veterinary clinical knowledge on contagion essential to the exclusion of sick animals from the process of serum production. But above all, the decree recognized the bacteriological knowledge of veterinarians, making them responsible for the whole production process of sera, whether for a medical or a veterinary use. As a consequence, every pharmaceutical industry or laboratory which wanted to produce serum, had to employ a qualified veterinarian to manage the production process. This was very important for the commercialization of these substances on the animal side as it created professional ties between the producers of sera and their users - exclusively veterinarians, which conferred them an advantage over non-qualified practitioners.

Amongst all sera, the one against foot-and-mouth disease was of primary importance for veterinarians.

\section{Public and private production of serum against foot-and-mouth disease}

The control of foot-and-mouth disease had been the rationale behind the creation of the Alfort Laboratory. However, the first years of research on the disease were featured by the difficulties to experiment on large animals. Indeed, viruses were cultured in vivo (in living bodies) and farm animals were the only animals sensitive to the virus of the foot and mouth (Joubert and Mackowiak 1968; Röhrer 1969). In 1920, the German scientist Otto Waldmann showed that it was possible to contaminate guinea pigs through

\footnotetext{
${ }^{6}$ Journal Officiel, arrêté du 31 Octobre 1901. The name of the Laboratory had changed many times since 1901: Created Research Laboratory on infectious diseases of animals, the laboratory was named the National Laboratory of Veterinary Services in 1921. See Meurier and Blancou 2006, p. 80-81.

7 Journal Officiel of November, 7, 1901, Documents Parlementaires, Chambre, Annexe no. 2724: "Proposition de Loi ayant pour objet d'instituer un prix de $100000 \mathrm{Fr}$. à décerner à celui qui découvrira un remède contre la fièvre aphteuse”, présenté par M. Gellé, Député., pp. 50-52: p. 52.

${ }^{8}$ Journal Officiel of 6 February 1937, pp. 1586-1587: “Arrêté du 4 février 1937”.
} 
scarification of their feet, and experiments on foot-and-mouth disease revived all through Europe. The Alfort Laboratory demonstrated why the previous experiments had failed: the virus responsible for foot-and-mouth disease was not unique, but multiple. In order to get the immunized animals resistant to infection, they had to develop not one but several vaccines or sera targeting each type of virus. A vaccine is a substance prepared from the causative agent of a disease (bacteria or virus) which has been killed or attenuated in order to act as an antigen (and stimulates the creation of antibodies for a long-term immunity) without inducing the disease, whereas serum is the liquid that separates out when the blood coagulates. Collected from convalescent animals, the serum contains antibodies against the microbe responsible for a disease, thus protecting a healthy animal that has not been in contact with the virus or reducing the symptoms of a contaminated animal. The negative point with a serum is that conferred immunity is very short and useless to protect cattle on a long-term basis. The researchers of Alfort Laboratory, the veterinarians Henri Vallée, Henri Carré and Paul Rinjard, prioritized working on a vaccine. In 1926, pleased with their "formalinattenuated vaccine", they settled their first large-scale trial on more than one thousand cattle. ${ }^{9}$ However, despite its relative success, the vaccine was doomed to remain experimental as it targeted only one serotype of the virus, its length of immunity was very short (a few months) and most of all, the way of culturing the virus that had to be attenuated to make the vaccine was both too complicated and expensive for large-scale production. Indeed, the bovines used for the virus culture were used to being contaminated and had developed a sort of resistance against foot-and-mouth disease, which made their symptoms milder, with less ulcerations, sources for the virus collection. Unable to improve their vaccine, the researchers from the Veterinary Laboratory worked on other methods to immunize cattle against foot-and-mouth disease: the use of serum and blood therapy. The serum utilization against that disease was already an "old technique" developed by the physician Friedrich Loeffler in the Riems Institute in Germany at the very end of the nineteenth century. In France, this technique was not really used until the 1930s as "accidents" following blood injections used to happen. ${ }^{10}$ However, the researchers at the Alfort Laboratory thought it might be a valuable method since it was so difficult to produce a vaccine, and they spent time improving it (Vallée 1911). In 1939, the veterinarians Jean-Pierre Thiéry (researcher of the Alfort Laboratory) and André Jules Chrétien (director of the veterinary services of the Seine Department ${ }^{11}$ ) considered "hemotherapy" (the direct injection of blood) "a very secure and efficient method, diminishing or suppressing the economic losses consequent to the foot-and-mouth disease on bovines" as they had used it between January and October 1938 (Chrétien and Thiéry 1939, p. 59). Of course, the preparation of the serum necessitated first collecting blood from recovered animals. This operation was possible as the researchers from Alfort worked in close cooperation with the Sanitary Veterinarians of the Seine department. Only qualified veterinarians could determine precisely the right moment to bleed the animals, in order to get the maximum antibodies with the minimum risk of contamination. Only they knew how to maintain and manipulate the

\footnotetext{
${ }^{9}$ British national archives, Public Record Office, MAFF 189/326: Foot-and-mouth disease Europe, 1924 1959.

10 That we would call "anaphylactic" reactions.

11 The old name for Paris as a department.
} 
animals, how to bleed them as quickly as possible without any pain or negative consequences and how to handle fresh blood preventing it from contamination and coagulation.

Serum production was thus the result of a complete partnership between veterinary bacteriologists and veterinarians from the veterinary services, who were warmly thanked by Chrétien and Thiéry in their 1939 paper. They shared the same background in bacteriology and thus could guarantee the success of the final product. This methodology was the same as the one established by the Pasteur Institute, when it came to the purity controls or the attenuation process of the virus. Then the blood was separated through a "separator" (from the brand "AlphaLaval") to get rid of the red blood corpuscles and produce the serum. Finally, the sera from diverse animals were mixed to "obtain a serum of medium activity". The serum production could not be done outside the laboratory, as it required special equipment, time and know-how (especially microbial cultures and bacteriological methodology) for which veterinarians had a monopoly through the decree of 1937. But the veterinary services and the Research Laboratory of Alfort were not the only ones interested in the production of serum. Some pharmaceutical industriessuch as, for example, the Serlande Laboratory (Laboratory of Bacteriology) in L'Aigle (Department of Basse-Normandy) of Ludovic Blaizot (a physician trained at the Pasteur Institute) who delivered in priority his brother's veterinary association, l'Union des Vétérinaires Agricoles (UVA) (Pierre Blaizot was trained a veterinarian), or the Mérieux Institute in Lyon-were well aware of the possibility to develop a medical market against foot-and-mouth disease. All of them were held by or employed veterinarians in order to produce sera for medical use and had decided-perhaps because of the close contact they had with veterinarians within their institutes - to engage themselves in parallel in the development of veterinary pharmacy. The well-documented example of the Mérieux Institute is a good way to apprehend the special relations these institutes developed with veterinarians in order to expand their markets and in return, to study how serum against foot-andmouth disease helped them to settle a medical policy in opposition to the sanitary policy, giving them a good opportunity to transform their status vis-à-vis their rural clientele.

Created in 1895 by Marcel Mérieux, a chemist who had learnt microbiology at the Pasteur Institute, the Mérieux Institute specialized in the preparation of sera for a medical and a veterinary use as well as into veterinary substances for diagnostic (tuberculin ${ }^{12} /$ mallein $^{13}$ ). Marcel Mérieux and his son, Charles Mérieux (a physician who also studied bacteriology at the Pasteur Institute), started the production of serum against foot-and-mouth disease in 1926, according to the scientific principles established by the veterinarians of Alfort Laboratory. ${ }^{14}$ As for the veterinary services, the Mérieux Institute relied on veterinary practitioners to obtain basic material for the serum production: the source of the virus. But in order to multiply the number of

\footnotetext{
${ }^{12}$ A bacteriological substance extracted from cultures of tubercle bacillus and used to diagnose the disease on both humans and bovines.

${ }^{13}$ A bacteriological substance extracted from cultures of the bacteria Pseudomonas mallei, used to diagnose glanders, a disease of the horse contagious for humans.

${ }^{14}$ Private archives of Dr. Charles Mérieux, Marcel Mérieux Foundation: personal documents of Marcel Mérieux: Vallée 1922.
} 
practitioners involved with his institute as well as the sources of virus, Marcel Mérieux simplified the way of collecting viruses, asking for ulcerations instead of citrated blood, which had the double advantage to not require neither any agreement of the farmer nor the payment of compensations for removing the blood. In return, the veterinarians who had accepted to collaborate with the Mérieux Institute were delivered the serum in priority. It was thus a guarantee for them to supply the farmers' demand at the briefest delays, a crucial step towards the regular examination of their cattle. The pamphlet promoting the sera of the Mérieux Institute was perfectly clear: the collection of ulcerations and the serum delivery could only be the result of collaboration with "certified veterinarians", 15 and not local practitioners (or farmers themselves) who could have wanted to use sera. ${ }^{16}$ The vocabulary and the tone of the pamphlet insisted on the scientific method that practitioners had to follow: the mastery of the collection gesture to keep active the virulence, the mastery of the right moment for removing the scrapings ${ }^{17}$ and the possession of water with glycerine could only have been the attributes of certified veterinarians trained at the National Schools of Veterinary Medicine. The ulcerations served in a second time to infect cattle belonging to the Mérieux Institute, stabled in a farm not far from Lyon, at Marcy l'Etoile. Increasing doses of viruses from multiple sources were used to infect the bovines through the scarification of their tongues, so that they became "hyper-immunes" once recovered. A veterinarian employed by the Mérieux Institute was then entrusted with the specific task of collecting their blood according to the procedure established by Alfort researchers, between the 12th and the 15th days after the appearance of the ulcerations, then the blood was sent to the main buildings of the Mérieux Institute (in Lyon) to be separated in serum. In its unpublished autobiography, Charles Mérieux remembers well the difficulty to manipulate the large quantity of blood from Marcy l'Etoile to Lyon, indispensable to the production of large quantities of serum: "We were back from Marcy with 3 litre bottles and the big problem was to prevent the blood from coagulating ${ }^{18}$ ". But the problem of blood coagulation was not the only one that Charles Mérieux had to deal with. To conquer the emerging market of serum therapy against foot-and-mouth disease, it was essential that the Mérieux Institute could satisfy the demand of the veterinarians and the farmers. Charles Mérieux then imported a technique from Denmark, "the serum dilution at $10 \%$ ", mixing his own serum with other serum produced with blood collected in farms from the neighbourhood, a technique to increase serum production that Charles Mérieux called the "lark pâté formula":

"We mixed our own serum with the one collected in the neighbourhood [...] We multiplied the production from one to one hundred. And the serum enabled us to earn more than one million francs in 1938. But it was very difficult to organize

\footnotetext{
15 "des vétérinaires diplômés".

${ }^{16}$ Private archives of Dr. Charles Mérieux, Marcel Mérieux Foundation: personal documents of Marcel Mérieux: pamphlet of Marcel Mérieux on the Institut Biologique Mérieux's behalf: "Prévention et traitement de la fièvre aphteuse par le sérum de bovidés guéris et hyperimmunisés", Septembre 1926.

${ }^{17}$ As soon as the animal had a maximum hyperthermia, about 2 or 3 days after the first symptoms of the disease.

${ }^{18}$ Private archives of Dr. Charles Mérieux, Marcel Mérieux Foundation: BOITE B 28, private documents of Dr. Charles Mérieux: Charles Mérieux's unpublished autobiography.
} 
and it remained very artisanal. I brought back the serum on the evening, my wife had to come and get it at Marcy and my sister mailed it in the afternoon. ${ }^{19}$,.

The serum was produced at the Mérieux Institute according to the method of the veterinary services. Bloods from various animals were mixed and citrated, then an antiseptic was added. Then serum was separated from the cells, through an "AlphaLaval" separator. The innocuousness and "therapeutic value" of the serum was tested on guinea pigs, very sensitive to foot-and-mouth disease. ${ }^{20}$ On their pamphlets, the pictures used by the Mérieux Institute as a commercial argument are very far from the lark-pâté formula. They show many machines involved in the serum preparation without any special comment. The technology-speaking for itselfwas used as a warrant for the scientificity and the solidity of the Institute, which veterinarians could rely on. Since 1937-the very beginning of his direction of the familial Institute - Charles Mérieux chose to use science as a marketing strategy to impose himself into the very narrowed world of French bacteriology, devoted to the glory of the Pasteur Institute. It was the same strategy that veterinarians had chosen to impose them as practitioners who could rely on science to control animal diseases, and Mérieux knew it. In order to become the first producer of serum against FMD, he chose to please and favour them with the sale of his products, without delivering anything to pharmacists. This strategy was followed by other laboratories such as Serlande for example. In return, the veterinary union had established a label that industrialists who had chosen to boycott pharmacists could stamp on their products. Veterinarians bought preferentially drugs that were labelled, to give advantage to the pharmaceutical industries favouring their profession. This exclusive market was the basis of the special relationship between the veterinarians and the Mérieux Institute, which reached a climax with the production of serum against FMD. Without the veterinarians, the Institute would not have been able to produce sufficient quantities of serum to supply the demand, thus would have been unable to impose itself on the veterinary market of prophylactic substances. In exchange, the veterinarians collaborating with the Institute were delivered the substances in priority, without any mediator, which was crucial to confer them a monopoly over the utilization of these substances. This strategy was very important to them, who got used to using Mérieux's products, whatever they were. Especially, they were very enthusiastic regarding the control of foot-and-mouth disease by the use of the serum, estimating that "the global results [were] absolutely remarkable" (Poillon 1934, p. 60). Thus, with the blood and ulcerations collection and the direct delivery of prophylactic substances, the Mérieux Institute gave tacitly a double monopoly to veterinarians, not only over the control of contagious diseases but also over the preservation of healthy animals. Despite the fact that this monopoly came from the private sector, it contributed to lead the French Government to give a mandate to veterinarians on the medicine of animals.

\footnotetext{
${ }^{19}$ Private archives of Dr. Charles Mérieux, Marcel Mérieux Foundation: BOITE B 28, private documents of Dr. Charles Mérieux: Charles Mérieux’s unpublished autobiography. My translation.

${ }^{20}$ Private Archives of Dr. Charles Mérieux, Marcel Mérieux Foundation: Personal Documents of Marcel Mérieux: Pamphlet of Marcel Mérieux on the Institut Biologique Mérieux's behalf: "Prévention et traitement de la fièvre aphteuse par le sérum de bovidés guéris et hyperimmunisés”, Septembre 1926.
} 


\section{The use of sera to control the 1938 epizootic of FMD and the development of the veterinary professional status}

When a terrible outbreak of foot-and-mouth disease started in 1937, the Deputy Albert Daille, who was a veterinarian and Professor at the Veterinary School of Toulouse, expressed the opinion of the French elites in charge of dealing with cattle diseases - the Agricultural Commission about Foot-and-Mouth Disease-in front of the Parliament:

"The best way to dry up the spread of contagion is the slaughtering of contaminated animals and of those, which, without any symptoms, could have contracted the disease. Rigorous disinfection of the contaminated areas must be carried out. $^{21}$,"

Like his colleagues, members of scientific Academies and Teachers of Veterinary Schools, such as Emmanuel Leclainche, ${ }^{22}$ Albert Daille and with him, the French government, were favourable to the generalization of the sanitary policy of isolation and "stamping out" for every contagious disease. However, the government quickly appeared publicly unable to establish such a policy, reluctant both to compensate for the losses of a compulsory slaughter of too many animals and to employ enough sanitary inspectors to enforce the legislation. The Senate - the second governing body responsible for the vote of laws in France (with the Assembly) - agreed reluctantly to abandon the sanitary policy as long as the incidence of the disease was so high, but kept noticing that the "stamping-out" sanitary policy had to be established in France as soon as possible:

"We do think that if the slaughtering of contaminated animals can not be achieved now that the epizootic is widespread, it is indispensable that in future outbreaks, the Ministry of Agriculture should dispose of sufficient funds to have contaminated animals slaughtered to dry out the spread of contamination from the beginning of the epizootic, method called the "stamping-out", which is used courageously in Great-Britain and Switzerland, and seems to have given satisfactory results. ${ }^{23}$,

Facing its failure to establish such a policy and unable to impose himself on any regulation, the French government tolerated the various local attempts to control footand-mouth disease whether led by the departmental veterinary services or private

\footnotetext{
${ }^{21}$ Journal Officiel, Chambre des Députés, séance du 3 juin 1937: Discussion, après demande de discussion immédiate, d'un projet de loi relatif à la prophylaxie de la fièvre aphteuse. M. Daille, Député, rapporteur de la Commission d'Agriculture, pp. 1789-1793, p. 1790. My translation.

22 President of the "Office International des Epizooties" (International Animal Health Organization) and Director of the French Veterinary Services for the Ministry of Agriculture.

23 Journal Officiel, Documents parlementaires, Sénat, annexe no. 601, séance du 14 décembre 1937, pp. 476477, p. 477: M.Dorgeot, 'Rapport fait au nom de la Commission de l'Agriculture, chargée d'examiner la proposition de résolution de M. Edouard Néron, tendant à inviter le gouvernement à proposer d'urgence au Parlement le vote des crédits nécessaires pour venir en aide aux petits cultivateurs (propriétaires, fermiers ou métayers) ruinés par l'épizootie actuelle de fièvre aphteuse et pour mettre à la disposition des services compétents les moyens matériels d'entreprendre et de conduire à bien la lutte contre toutes les maladies contagieuses qui déciment le cheptel national.” My translation.
} 
laboratories, together with veterinary practitioners. One could have expected to see the veterinary services (now a branch of the Ministry of Agriculture) well engaged in the surveillance of contagious diseases on fairs and markets, in slaughterhouses and at borders, getting involved with the rigorous application of the sanitary policy in case of foot-and-mouth disease. But paid as local administrators by the departments (they became departmental veterinary officers in 1919), they were used to dealing directly with local authorities, enabling them to act without reporting to their Ministry or waiting for its approval. Thus, they had kept a relatively important autonomy, leaving them free to engage in the production of prophylactic substances, such as sera against foot-and-mouth disease, which were delivered to the farmers in need for assistance. Indeed, some departments had invested in the creation of laboratories that belonged to the veterinary services, in order to offer their services to farmers and control animal diseases on a local level, with the help of liberal veterinarians. The diffusion of prophylactic substances had benefitted from the soft application of the sanitary policy, which, without promoting other ways of controlling diseases, did not consider them illegal. The government, however, was clearly lost in this situation. In order to apprehend what was happening in the various departments, the head of the veterinary services (a member of the Ministry of Agriculture) sent an official letter to all the departmental directors of the veterinary services, to determine which prophylaxis they had chosen to establish:

"Sir, I have the honour to request that you inform me, without delay, if a Centre for the collection, storage and distribution of blood from animals recovered from foot-and mouth disease is established and operational in your Department. If it is so would you please fill in the following questionnaire, to be sent with your letter:

date of opening of the Centre

buildings: situation, number and width

employees

equipment

global costs of the Centre for its installation

annual costs for the functioning of the Centre

sources of funding for the functioning and the installation of the Centre

annual assessment of the Centre, since its installation:

quantity of collected blood (in litres)

quantity of blood supplied (in litres)

costs of functioning

costs of blood collection

costs of blood delivery

benefits

balance

In the case of there not being any Centre in your Department, just specify "none" in your letter. ${ }^{24,}$

\footnotetext{
${ }^{24}$ French national archives, Centre des Archives Contemporaines, Ministère de l'Agriculture, Fonds des Services Vétérinaires, cote no. 19880158, Article 46, Order by the Head of the Veterinary Services to the Directors of the Departmental Veterinary Services dated October 2, 1937. My translation.
} 
This letter demonstrates that contrary to what is generally written about France, a very centralized country, with a bureaucratized administration, the cooperative actions between farmers and veterinarians - whether private practitioners or employed by the sanitary services - were local initiatives, completely independent from any governmental pressure or global veterinary recommendation (from the Veterinary National Syndicate or the elites). "We were not suspended to Paris agreement to establish something ${ }^{25,}$ declared, with shining eyes, Pierre Bonnaud, a veterinary practitioner in the department of Vendée (North West France), demonstrating that local initiatives, together with the personality of the various veterinarians involved with these prophylactic techniques, were much more efficient than official recommendations. These local initiatives reveal that veterinary practitioners, far from their elites, saw much more their professional interest within the development of a relationship with farmers based on trust and cooperation (similar to the physician/patient relationship), with animals preserved or cured. This position was in complete agreement with their professional oath: "first do not harm". On the contrary, sanitary policy was more negatively perceived, associated with the feeling of being "police officers" in charge of the repressive measures of isolation and stamping out. ${ }^{26}$

The blood or serum was injected into the cattle of farmers in demand for such prophylaxis. As it was not compulsory nor experimental, the farmers had to pay for the serum therapy, which defined a new medical market for cattle, different from the ones of folk practitioners. Preventing animals from being contaminated by a contagious disease meant preventing the massive losses the farmers had to encounter, whether by the morbidity of the disease or by the application of the sanitary policy. M. Robert, a veterinarian at La Roche-sur-Yon, in Vendée (North West France), remembers well the farmers' enthusiasm for the "hémoprévention", when veterinarians had to perform real

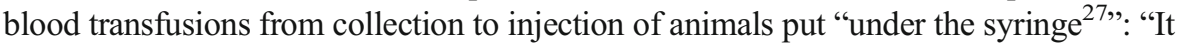
was quite difficult, but globally, we obtained some good results ${ }^{28}$ ". These "good results" sealed a new relationship with farmers, where veterinarians appeared as trusty advisers, providing ways of protecting their cattle from ravages of the disease. The

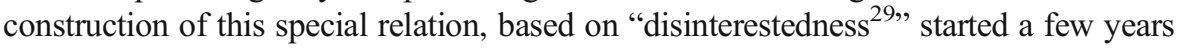
before with the legislation against bovine tuberculosis (in 1933). The French Syndicate of Veterinarians ${ }^{30}$ pleaded to become the farmers' advisors by letting them be free to decide whether they wanted to eradicate bovine tuberculosis or not, with the help of a veterinarian, seen as an advisor. Veterinarians also tried to "acculturate ${ }^{31}$ " farmers to their way of dealing with animal diseases, popularizing their role of "advisors" in

\footnotetext{
${ }^{25}$ Interview of Pierre Bonnaud, dated February 14, 2007, made at La Roche-Sur-Yon, Vendée, with JeanJacques Bénet, Professor of Veterinary Medicine at the National Veterinary School of Alfort. My translation. ${ }^{26}$ M. Villemin, Les vétérinaires français au XIXe siècle, 1982, p. 188 cité par Conseil Général Vétérinaire 2006, p. 50. My translation.

${ }^{27}$ Quoting Pierre Guillon: “sous la seringue”, Interview dated February 14, 2007, made at La Roche-Sur-Yon, Vendée, with Jean-Jacques Bénet, Professor of Veterinary Medicine at the National Veterinary School of Alfort.

${ }^{28}$ Interview of M. Robert, dated February 14, 2007, made at La Roche-Sur-Yon, Vendée, with Jean-Jacques Bénet, Professor of Veterinary Medicine at the National Veterinary School of Alfort. My translation.

29 According to Lucien Karpic, "disinterestedness" both rejects allegiance to the State and submission to the market forces, by constructing a special relationship with the public (Karpik 1995).

${ }^{30}$ Syndicat National des Vétérinaires de France et des Colonies

${ }^{31}$ Farmers assimilated the veterinary culture of disease which was different from their own way of dealing with animal diseases.
} 
various pamphlets addressed to farmers, such as "Gare à la Cocotte!" ("Beware of the Cocotte!') by the veterinarian Fernand Vélat (1907). Thus, the veterinarians built their own medical market of prophylactic substances through the commercialization of sera against foot-and-mouth disease, whose main attraction was to prevent the morbid symptoms of the disease, such as folk remedies. But the essential difference with folk remedies was that sera against foot-and-mouth disease were produced exclusively by veterinarians and sold exclusively to veterinarians. By choosing to use it only on healthy animals to fully prevent the disease, they performed a medical care to animals beyond their jurisdiction based on the control of contagious animals. In doing so, veterinarians developed an interaction network between "humans" and "non-humans" (Latour and Callon 1991) essential for the development of their profession from the medicine of contagious animals to the medicine of all animals, where the use of the syringe was to be a decisive mediator (Akrich 1993) into the establishment of a confidence relationship between farmers and veterinarians. This special relationship with farmers served the achievement of the development of veterinary profession: veterinarians used their success against foot-and-mouth disease to demonstrate that the control of contagious diseases could only succeed if certified veterinarians acted before the contagious agent, by the exclusive control over the health of all animals.

As Andrew Abbott stated, the development of professions is comparable with a system which makes various occupations redefine their competences according to the move of other occupations with whom they share frontiers (Abbott 1988). In their attempt to exclude non-qualified practitioners from the medicine of animals, veterinarians, defended by the deputy Jules Mitton, redefined the borders of their profession, centring their practice on the "clinic" and medical prophylactics, and leaving some of their technical skills to their rivals:

"If it is necessary, for the sake of agriculture and animal health, that nowadays, the medicine and the surgery of animals should be reserved to veterinarians, it should not be a question to modify certain traditional practices and to give prejudice on certain corporations. It is natural that farriers should treat foot accidents and practice some interventions related to their own skills. No one could imagine suppressing the antique corporation of castrators. ${ }^{32,}$

Veterinarians abandoned operations of the feet and castrations (of every animal but the horse) to other corporations that they called "farriers" and "castrators", and not "marshalexpert", as the expertise on animal health was the attribute of certified veterinarians.

\section{The system of professions: "marshal-experts" reduced competences and the new definition of the veterinary expertise}

But the "marshal-experts" (from the French word maréchal-experts, meaning expert farrier) were gathered around a representative body, the National Federation of

\footnotetext{
${ }^{32}$ Journal Officiel, Documents Parlementaires, Chambre, Séance du 8 Juin 1937, Annexe no. 2562: Rapport fait au nom de la commission de l'agriculture chargée d'examiner le projet de loi relatif à l'exercice de la médecine vétérinaire, par M. Mitton, député, pp. 708-710, p. 709. My translation.
} 
"Marshal-experts" and "Castrators" of France (the Fédération Nationale des Maréchaux Experts et Hongreurs de France), with their own specialized press. ${ }^{33}$ They were numerous and often well considered whether in the countryside or in the Assembly, as they benefitted from many parliamentary supports. Struggling to maintain and develop their corporation, the folk practitioners refused to have their competences reduced to these simple operations. Through parliamentarians well aware of their influence in the countryside, they counteracted the project of the veterinarians, insisting on the fact that 2400 veterinarians could not do the job of more than 8000 "marshal-experts". 34 They insisted on the competences acquired by experience of diseases, whether in the field, in their professional school or in the Army, justifying their "expert" qualification:

"What is a "marshal-expert"? The marshal-experts, precursors of the veterinarians, had been curing animals for centuries, and their sons render the same kind of services with the same loyalty, generally collaborating with veterinarians. As numerous as 8000, they have founded a large syndicate, the 'National Federation of French Expert-Marshals' in 1929, this syndicate has founded a professional school, which forms pupils during 3 years and tests their competences. ${ }^{35}$,"

Thus, both their knowledge and their certification, as well as their presence in the field made them the essential assistants of veterinarians, such as nurses, assisted physicians in a hospital:

"All liberal professions have their second order qualification. Next to the lawyer, there is an aide's capacity; next to the physician, there is a nurse, a midwife. It thus seems illogical that all but the veterinary profession has qualified auxiliaries. $^{36,}$

In that perspective, "marshal-experts" would have perfectly been able to deliver prophylactic substances to their clients, such as nurses could vaccinate babies against tuberculosis for example (Bonah 2006), all the more than the vaccinated or "serumized" animal should have been perfectly healthy when inoculated. Thus, nothing but the tacit monopoly between producers and practitioners prevented any other person to use the new prophylactic substances. Folk practitioners, by the intermediary of their parliamentary supports, attempted to put a hand on these substances, whether diagnostic or preventive and to break down the tacit veterinary monopoly. This new menace led the veterinarians towards their final struggle against farriers to prevent them from exercising the medicine of non-contagious animals. In that struggle, their empirical experience with the serum therapy against foot-and-mouth disease was to be determinant. To definitely close the debates, the deputy Jules Mitton enumerated the various

\footnotetext{
${ }^{33}$ La Maréchalerie, Le Maréchal et le Charron Modernes, ou encore la Revue des Maréchaux-Experts et Hongreurs de l'Ouest.

34 Journal Officiel, Chambre des Députés, Séance du 28 janvier 1938, "Discussion d'un projet de loi relatif à l'exercice de la médecine vétérinaire", pp. 142-154, p. 144.

35 Journal Officiel, Documents Parlementaires, Chambre, annexe no. 3507, Séance du 27 janvier 1938, Proposition de Loi tendant à l'organisation de la médecine vétérinaire, pp. 76-77, p. 76. My translation.

36 Journal Officiel, Chambre des Députés, Séance du 28 janvier 1938: "Discussion d'un projet de loi relatif à l'exercice de la médecine vétérinaire", pp. 142-154, p. 145. My translation.
} 
contagious diseases that handicapped the agricultural economy. According to him, only certified veterinarians were able to control all contagious diseases (more than those of the $1881 \mathrm{Act}$ ). ${ }^{37}$ And because this control was not only an individual problem of the owner of the animals but also a collective problem affecting the global economy of the country, he pleaded that the government should legislate to empower a body of specialists of contagion to prevent the contamination of healthy animals. Debating about contagion in 1938, when a strong and uncontrollable outbreak of foot-and-mouth disease was responsible for important losses in money and food, was a very strong argument. It brought to silence the defenders of marshal-experts, all the more when the Veterinary Direction of the Ministry of Agriculture was studying the possibility of generalizing the serum therapy. The idea was to mobilize private veterinarians (using serum produced by pharmaceutical companies or by the veterinary services) to control the spread of contagion before imposing the slaughtering of contaminated animals. ${ }^{38}$ For the Ministry of Agriculture, it was a cheap prophylaxis, mainly assumed by the farmers who had agreed to pay for the veterinary expertise as well as for the serum. Moreover, as everything had already been organized locally, either by departmental veterinarians or by liberal practitioners, the government did not even have the burden of cost of the administrative organization. With the success of serum therapies on bovines against foot-and-mouth disease, the veterinarians imposed themselves as the body of reference to control the health of animals whether sick or healthy. Eventually, the State determined the unequal conditions of competition between farriers and veterinarians, conferring the latter a monopoly on animal medicine with the June, 17, 1938, Act, while the former saw their territory restricted according to the veterinary will.

\section{Conclusion: a professional equilibrium between medicine and pharmacy}

Since the second half of the nineteenth century, French veterinarians had envied the status physicians managed to secure, with the disappearance of the sanitary officers (who were not certified physicians) in 1892. But contrary to physicians, the absence of a mandate from the State to control the health of animals made veterinarians depend on other strategies to impose themselves in farms. Amongst them, the sale of vaccines and sera was of first importance, thanks to the monopoly of delivery that producers of these substances conferred on veterinarians.

But this agreement with the private sector had nothing official nor mandatory. Marshal-experts and other folk practitioners, as well as professional agricultural associations and unions, started to ask for these substances that they wanted to use without calling for a veterinarian, like any other veterinary drug (Pinguet 1953). In order to get a legitimization by the State of their precarious market shelter, the veterinary union mobilized the same rhetorical arguments its representatives had used with the serum against foot-and-mouth disease. They insisted on the special skills veterinarians had

\footnotetext{
37 Journal Officiel, Chambre des Députés, Séance du 28 janvier 1938: "Discussion d'un projet de loi relatif à l'exercice de la médecine vétérinaire", pp. 142-154, p. 147-148.

${ }^{38}$ French national archives, Centre des Archives Contemporaines, Ministère de l'Agriculture, Fonds des Services Vétérinaires, cote no. 19880158, Article 46, Circulaire du Ministre de l'Agriculture à Messieurs les Préfets, du 20 octobre 1937.
} 
acquired through their formation, their mastering of bacteriological and technical skills indispensable to the careful and optimal utilization of sera, vaccines and other substances from "microbial origin". 39 The example of the diagnostic test of bovine tuberculosis through the tuberculin test-described through an administrative threepage document - shows very well how the injection of the microbial substance and the interpretation of the clinical reaction which follows made tuberculin injection a working knowledge - a technical skill based on a careful, informed knowledge (Pickstone 2007) — that only certified veterinarians could possess. ${ }^{40}$ In that sense, the use of syringes containing microbial substances reinforced the medical role of veterinarians who saw both financial benefits in the direct sale of these products and also the core meaning of their work as practitioners of animal medicine, as those substances were most of the time used to prevent contagious diseases or to reduce the symptom of a disease. The ethos of a medical prophylaxis is far from what requires the application of a sanitary policy based on the slaughtering of contagious animals (Berdah 2018). Thus, the use of vaccines and sera contributed to the organization of a pharmaceutical activity that seemed essential both to the idea of what should be a veterinary act and most of all, to the development of the economic system of rural veterinarians. Later, these working knowledge were enlarged to the mastering of all drugs veterinarians could possess (most of all antibiotics) even more after the law of 1975 on veterinary pharmacy. Thus, the veterinary drug market became the cornerstone of veterinary practices, what the sociologists Laure Bonnaud and Nicolas Fortané describe as "a captive market where drug sales have gradually become the only monetized exchange between veterinarians and farmers, funding all the services actually offered by veterinarians" (Bonnaud and Fortané 2018). This economic system has been recently criticized by a coalition of human health actors as it was blamed for contributing to the significant development of antibiotic resistance (Fortané 2020). The arguments of the profession, as well as their involvement in favour of preventive veterinary medicine, based on a careful and rational use of antibiotics that only veterinarians could master (described by Nicolas Fortané in this issue), seem then a revival of their previous professional struggles where both the working knowledge associated with the mastering of sera-especially those against foot-and-mouth disease - and the commercialization of the substances, contributed to ascertain their status and their representation of what should be a veterinary act.

\section{Compliance with ethical standards}

Conflict of interest The author declares that there is no conflict of interest.

\section{References}

Abbott, A. (1988). The system of professions: an essay on the division of expert labour. Chicago: The University of Chicago Press.

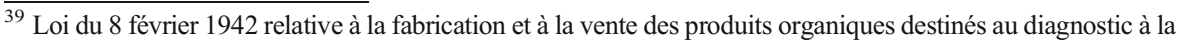
prévention et au traitement des maladies des animaux: Journal Officiel, 13 février 1942, p. 634 and Décret du 14 février 1952: Journal Officiel du 19 février 1952, pp. 2054-2055.

${ }^{40}$ Arrêté du 12 Octobre 1953: "Méthodes de tuberculination à mettre en œuvre en vue des opérations de rédhibition pour cause de tuberculose bovine". Journal Officiel du 16 octobre 1953, p. 9212-9214.
} 
Akrich, M. (1993). Les formes de médiation technique. Réseaux, 60, 87-98.

Berdah, D. (2012). Entre scientifisation et travail de frontières : les transformations des savoirs vétérinaires en France, XIXe - XIXe siècles. Revue d'Histoire Moderne et Contemporaine, 59(4), 51-96.

Berdah, D. (2018). Abattre ou vacciner ? Histoires croisées de la lutte contre la fièvre aphteuse et la tuberculose bovine en France et au Royaume-Uni, 1900-1960. Paris: Editions de l'EHESS.

Blancou, J. (2003). History of the surveillance and control of transmissible animal diseases. Paris: Office International des Epizooties.

Bonah, C. (2006). 'As safe as milk or sugar water.' Perceptions of the risks and benefits of the BCG vaccine in the 1920s and 1930s in France and Germany. In T. Schlich \& U. Troehler (Eds.), The Risks of Medial Innovation. Risk Perception and Assessment in Historical Context (pp. 71-92). London: Routledge.

Bonnaud, L., \& Fortané, N. (2018). L'état sanitaire de la profession vétérinaire. Action publique et régulation de l'activité professionnelle. Sociologie, 3(9), 253-268.

Cassier, M. (2005). Appropriation and commercialization of the Pasteur anthrax vaccine. Studies in History and Philosophy of Science Part C : Studies in History and Philosophy of Biological and Biomedical Sciences, 36(4), 722-742.

Cassier, M. (2008). L'invention et la diffusion du vaccin charbonneux. Pasteur, entre science, agriculture et nouvelle industrie biologique. In C. Bonneuil, G. Denis, \& J.-L. Mayaud (Eds.), Science, Chercheurs et Agriculture, Alimentation (pp. 61-86). Paris: Éditions Quae/INRA.

Chrétien, J. \& Thiéry, J.P., (1939). L'hémoprévention contre la fièvre aphteuse dans le département de la Seine et dans quelques exploitations de la région parisienne. Bulletin de l'Académie Vétérinaire de France, 12(5 janvier), 49-59.

Conseil Général Vétérinaire. (2006). Histoire des services vétérinaires français. Paris: Association Amicale du Conseil Général Vétérinaire.

Eme, C. (1912). De la fièvre aphteuse et des moyens de la combattre. Pontarlier: Imprimerie Faivre.

Fisher, J. R. (1993). Not quite a profession. The aspirations of veterinary surgeons in England in the midnineteenth century. Historical Research, 66(161), 284-302.

Fleck, L. (2005). [1934]. Genèse et développement d'un fait scientifique. Paris: Les belles lettres.

Fortané, N., (2020) PVM to the rescue of veterinarians? Antimicrobial resistance, professional expertise and business model of French veterinarians. Review of Agricultural, Food and Environmental Studies, forthcoming.

Friedson, E. (1988). [1986]. Professional powers: a study of the institionalization of formal knowledge. Chicago: University of Chicago Press.

Geison, G. L. (1997). [1995]. The private science of Louis Pasteur. Princeton: Princeton University Press.

Hardy, A. (2003). Professional advantage and public health : British veterinarians and state veterinary services, 1865-1939. Twwentieth Century British History, 14(1), 1-23.

Hubscher, R. (1999). Les maîtres des bêtes. Les vétérinaires dans la société française, XVIIIe-XXe siècles. Paris: Odile Jacob.

Joubert, L., \& Mackowiak, C. (1968). La fièvre aphteuse. Lyon: Fondation Mérieux/Expansion Scientifique. Jouët, F. (1912). L'affection aphteuse, étiologie et traitement. Nyons: Imprimerie administrative E. Germain.

Karpik, L. (1995). Les avocats entre l'État, le public et le marché, XIIIe-XXe siècle. Paris: Gallimard.

Koolmees, P. (1988). Meat inspection in the Netherlands during the 19th century. Deutsche Tierärztliche Wochenschrift, 95(10), 438-439.

Lascoumes, P. (1990). Normes juridiques et mise en œuvre des politiques publiques. L'année sociologique, $40,43-71$.

Latour, B., \& Callon, M. (Eds.). (1991). La Science telle qu'elle se fait : anthologie de la sociologie des sciences de langue anglaise. Paris: Éditions La Découverte.

Mayaud, J. L. (2000). La petite exploitation rurale triomphante, France, XIXe siècle. Paris: Belin.

Mayaud, J. L. (2002). Gens de la Terre. La France Rurale, 1880-1940. Paris: Éditions du Chêne - Hachette Livre.

Meurier, C., \& Blancou, J. (2006). Brève histoire de quelques laboratoires nationaux français: première partie. Bulletin de la Société Française d'Histoire de la Médecine et des Sciences Vétérinaires, 6, 79-107.

Mitsuda, T. (2017). Entangled histories: German veterinary medicine, c. 1770-1900. Medical History, 61(1), $25-47$.

Morandi, L. (Ed.). (n.d.). Rapport sur l'emploi du thym et du serpolet, d'après le procédé de Luigi Morandi, contre la fièvre aphteuse. Milano: Istituto S. Gaetano.

Pickstone, J. (2007). Working knowledges before and after circa 1800. Practices and disciplines in the history of science, technology and médicine. Isis, 98(3), 489-516.

Pinguet, M. (1953). Adaptation de la vétérinaire à l'évolution des différentes productions animales. Bulletin du Syndicat National des Vétérinaires Français, janvier-février, 3-8. 
Poillon, C. H. (1934). La Fièvre Aphteuse, sa prophylaxie, quelques observations sur l'emploi du sérum antiaphteux. Paris: Vigot Frères.

Röhrer, H. (1969). Traité des maladies à virus des animaux. Paris: Vigot Frères Editeurs.

Rosset, R. (2003). Pasteur et les Vétérinaires. Bulletin de la Société Française d'Histoire de la Médecine et des Sciences Vétérinaires, 2(2), 1-23.

Schäffer, J., \& Koolmees, P. (Eds.). (2003). History of veterinary medicine and agriculture. Giessen: DVG.

Stanziani, A. (2005). Histoire de la qualité alimentaire, XIXe-XXe siècles. Paris: Seuil.

Vallée, H., (1911). Etudes sur la Fièvre Aphteuse. Pont-Audemer : Imprimerie du Commerce.

Vallée, H., (1922). Les récentes acquisitions sur la fièvre aphteuse. Bulletin de la société des sciences vétérinaires de Lyon, 5-6, sept-dec.

Vélat, F. (1907). Gare à la Cocotte ! Petite Encyclopédie Populaire Illustrée: Amiens.

Waddington, K. (2004). To stamp out "so terrible a malady". Bovine tuberculosis and tuberculin testing in Britain, 1890-1939. Medical History, 48, 29-48.

Waddington, K. (2006). The bovine scourge : meat, tuberculosis and public health, 1850-1914. Woodbridge: Boydell Press.

Wilkinson, L. (1992). Animals and disease. An introduction to the history of comparative medicine. Cambridge: Cambridge University Press.

Woods, A., (2004). A manufactured plague ? The history of foot-and-mouth disease in Britain, LondresSterling : Earthscan.

Woods, A. (2011). A historical synopsis of farm animal disease and public policy in twentieth century Britain. Philosophical Transactions of the Royal Society B, 366(1573), 1943-1954.

Woods, A. (2013). From practical men to scientific experts: British veterinary surgeons and the development of government scientific expertise, c.1878-1919. History of Science, 51(4), 457-480.

Woods, A., \& Matthews, S. (2010). 'Little, if at all, removed from the illiterate farrier or cow-leech': the English veterinary surgeon, c. 1860-85, and the campaign for veterinary reform. Medical History, 54(1), 29-54.

Worboys, M. (1991). Germ theories of disease and British veterinary medicine, 1860-1890. Medical History, 35(3), 308-327.

Worboys, M. (1992). Killing and curing. Veterinarians, medicine and germs in Britain, 1860-1900. Veterinary History, 7(2), 53-71.

Publisher's note Springer Nature remains neutral with regard to jurisdictional claims in published maps and institutional affiliations.

\section{Affiliations}

\section{Delphine Berdah ${ }^{1}$}

1 Université Paris-Saclay, Etudes sur les Sciences et les Techniques (EST), 91400 Orsay, France 